\title{
A Carboxy-terminal Truncated Insulin Receptor Substrate-1 Dominant Negative Protein Reverses the Human Hepatocellular Carcinoma Malignant Phenotype
}

\author{
Shinji Tanaka and Jack R. Wands \\ Molecular Hepatology Laboratory, Massachusetts General Hospital Cancer Center and Harvard Medical School, Charlestown, \\ Massachusetts 02129
}

\begin{abstract}
Insulin receptor substrate-1 (IRS-1), a substrate of various receptor tyrosine kinases transmits mitogenic signals initiated by extracellular ligands. This protein is involved in normal hepatocyte growth and has been found to be overexpressed in human hepatocellular carcinoma. Expression of a carboxy-terminal truncated IRS-1 molecule containing the pleckstrin homology and phosphotyrosine-binding domains associates with the insulin receptor and prevents tyrosyl phosphorylation of endogenous IRS-1 and Shc proteins. Thus, subsequent activation of downstream signaling molecules induced by insulin and IGF-1 such as phosphatidylinositol-3 kinase and mitogen activated protein kinase is inhibited. The morphologic features of transformed human hepatocellular carcinoma cells change to a differentiated hepatocyte appearance and characteristics of the malignant phenotype as manifested by anchorage independent cell growth and tumor formation in nude mice are lost. These studies demonstrate that signal transduction pathways mediated through or by IRS-1 are important in hepatocyte and human hepatocellular carcinoma cell growth. (J. Clin. Invest. 1996. 98:2100-2108.) Key words: human hepatoma • signal transduction $\bullet$ carcinogenesis
\end{abstract}

\section{Introduction}

Human hepatocellular carcinoma $(\mathrm{HCC})^{1}$ is one of the most common tumors in the world today (1). Studies related to understanding the cellular mechanisms of unrestrained hepatocyte growth may have relevance to the pathogenesis of the disease. Normal hepatocyte proliferation is regulated by several growth factors of which EGF, TGF $\alpha$, and hepatocyte growth factor (HGF) as type 1 stimulators and insulin and IGF-1 as

Address correspondence to Jack R. Wands, Molecular Hepatology Laboratory, MGH Cancer Center, Bldg. \#149, 13th Street, 7th floor, Charlestown, MA 02129. Phone: 617-726-5601; FAX: 617-726-5609.

Received for publication 10 May 1996 and accepted in revised form 30 August 1996.

1. Abbreviations used in this paper: $\mathrm{HCC}$, hepatocellular carcinoma; HGF, hepatic growth factor; hIRS-1, human insulin receptor substrate-1; MAPK, mitogen-activated protein kinase; MBP, myelin basic protein; $\mathrm{PH}$, pleckstrin homology; PI3K, phosphatidylinositol-3 kinase; PTB, phosphotyrosine binding; SH, Src homology; TP, tyrosyl phosphorylation.

J. Clin. Invest.

(C) The American Society for Clinical Investigation, Inc. 0021-9738/96/11/2100/09 \$2.00

Volume 98, Number 9, November 1996, 2100-2108 type 2 stimulators are believed to be the most important ligands in this regard (2-4). Such growth factors bind to hepatocyte cell surface receptors with intrinsic tyrosine kinase activity and initiate a series of protein phosphorylation events within cells (1). Tyrosyl phosphorylation (TP) of downstream molecules transmits the mitogenic signals from the cell surface to the nucleus through several signal transduction pathways.

It is of interest that a cDNA encoding for one of the key molecules involved in the insulin mediated signal transduction cascade, namely human insulin receptor substrate-1 (hIRS-1), has been found to be overexpressed at the protein and RNA level in HCC cell lines and tumor tissues $(5,6)$. IRS- 1 is phosphorylated on tyrosine residues following cellular stimulation by ligands such as insulin, IGF-1, IL-4, -9, and -13, IFN $\alpha, \beta, \gamma$, and $\omega$, growth hormone, leukemia inhibitory factor, and tumor necrosis factor (7-11). Tyrosyl phosphorylated IRS-1 serves as a key "docking" protein and transmits mitogenic or metabolic signals by interacting through specific motifs with downstream SH2-containing molecules (12). For example, the ${ }^{897}$ YVNI motif of hIRS-1 binds to the Grb2 adopter protein (13), the ${ }^{1180}$ YIDL motif to Syp phosphatase (also known as PTP1D, PTP2C, and SH-PTP2) (14), and ${ }^{613}$ YMPM and ${ }^{942}$ YMKM motifs are the principal binding sites for the $\mathrm{p} 85$ subunit of phosphatidylinositol-3 kinase (PI3K) $(15,16)$. While TP sites are recognized throughout the entire IRS-1 protein, the SH2-binding domains are located only in the $\mathrm{COOH}$-terminal region (9). The $\mathrm{NH}_{2}$-terminal sequences, however, contain three important functional domains identified as a pleckstrin homology ( $\mathrm{PH})$ region located from 9-117 aa. (17) and two regions homologous to a phosphotyrosine-binding (PTB) domain located from 161-317 amino acid (aa) (18) and from 314-463 aa. (19).

It is noteworthy that normal hepatic growth has been associated with enhanced TP of IRS- 1 and subsequent interaction with $\mathrm{SH} 2$-containing molecules such as Grb2 and PI3K during the G1 phase of the hepatocyte cell cycle after partial hepatectomy (20). There is now evidence to support the hypothesis that IRS-1 may have transforming properties as well $(21,22)$. Stable transfection and overexpression of the $h I R S-1$ gene in NIH $3 \mathrm{~T} 3$ cells leads to increased TP of the protein, enhanced binding to Grb2 and Syp but not PI3K and persistent activation of the downstream mitogen-activated protein kinase (MAPK) cascade. Such transfected cells developed a phenotype characterized by increased transformed foci formation, induction of anchorage independent cell growth, increased cell proliferation, and formation of large tumors in nude mice (22). The functional domains of the hIRS-1 protein required for its transforming activity have been shown to reside in both the ${ }^{897}$ YVNI and ${ }^{1180}$ YIDL motifs (23). Other studies indirectly support the role of IRS-1 in mediating some of the cellular events associated with malignant transformation since insulin and IGF-1 have been shown to act as dominant cellular mitogens for several different human tumor types including HCC (24). 
In the present investigation, we have defined the functional domains of hIRS-1 essential for insulin and IGF-1 induced TP and necessary for subsequent activation of downstream signal transduction molecules associated with human hepatocyte transformation. Direct evidence for the relevance of these pathways in control of HCC growth is provided, since a dominant negative mutant protein that blocks TP of endogenous hIRS-1 protein and other substrates such as She will reverse the malignant phenotype of HCC cells.

\section{Methods}

Reagents. A poorly differentiated cell line (FOCUS) derived from a human hepatocellular carcinoma tumor (6) was used to clone the hIRS-1 cDNA. The FOCUS cell line contains one copy of integrated hepatitis B virus (HBV) DNA (25). The FOCUS and well differentiated HepG2 human hepatoblastoma cell lines were cultured in DMEM; (Mediatech, Washington, DC) supplemented with 10\% heat inactivated FBS (Sigma Chemical Co., St. Louis, MO). The moderately differentiated HuH-7 human HCC cell line was cultured in RPMI-1640 medium supplemented (Mediatech) with $3 \times 10^{-8} \mathrm{M} \mathrm{Na}_{2} \mathrm{SeO}_{3}$ (serum free) or with $10 \%$ FBS (26). Heat inactivated calf serum (GIBCO BRL, Rockville, MD) containing much lower concentration of insulin/ IGF-1 was also used for morphologic analysis of cell growth (27). For immunoprecipitation and immunoblot studies, and anti-IRS-1 rabbit polyclonal antibody (Upstate Biotechnology Inc., Lake Placid, NY), antiphosphotyrosine antibody conjugated with horseradish peroxidase (PY20H; Transduction Laboratories, Lexington, KY), anti-Shc rabbit polyclonal antibody (Transduction Laboratories), antiinsulin receptor rabbit polyclonal antibody (provided by Dr. X.F. Zhang, Massachusetts General Hospital), anti-FLAG M2 mouse monoclonal antibody (Eastman Kodak Co., Rochester, NY), anti-Grb2 rabbit polyclonal antibody (Santa Cruz Biotechnology, Santa Cruz, CA), anti-Syp/PTP2C mouse monoclonal antibody (Transduction Laboratories), and anti-p85 PI3K rabbit polyclonal antibody (Upstate Biotechnology Inc.) were used. MAPK activity was measured using myelin basic protein (MBP; Sigma Chemical Co.) as the specific substrate.

Construction of hIRS-1 mutants. The hIRS-1 deletion mutants were sequentially constructed using PCR or restriction enzymes digestion and have a FLAG epitope (DYKDDDDK+stop codon) added to the $\mathrm{COOH}$ terminus by PCR. The cDNA of each mutant IRS-1 construct was subcloned between the cytomegalovirus promoter and SV40 poly A regions of the pcDNA3 plasmid (Invitrogen Corp., San Diego, CA). The DNA sequence of each hIRS-1 mutant construct was determined using Sequenase Ver 2.0 (United States Biochemical Inc., Cleveland, OH).

Cell culture and transfection studies. Parental FOCUS HCC cells and clonal stable transfected cell lines (25) were cultured in DME supplemented with $10 \%$ heat FBS. HCC cells $\left(1 \times 10^{6}\right)$ were grown in $3.5-\mathrm{cm}$ dishes and transfected with $2 \mu \mathrm{g}$ of the various hIRS-1 mutant constructs as well as empty pcDNA3 (mock) plasmid using Lipofectamine (Life Technologies, Inc., Gaithersburg, MD) according to manufacturer's instructions. $2 \mathrm{~d}$ after transient transfection, cells were serum starved for $12 \mathrm{~h}$ to allow cells to accumulate in G1 of the cell cycle followed by $100 \mathrm{nM}$ insulin addition. To obtain stable transfected clones, neomycin-resistant colonies were isolated in the presence of G418 (800 $\mu \mathrm{g} / \mathrm{ml})$ in DME with 10\% FBS $2 \mathrm{~d}$ after a 1:10 split.

Immunoblot and immunoprecipitation analysis. Cell lysates derived from transfected HCC cells were prepared in Triton-lysis buffer (50 mM Tris- $\mathrm{HCl}, \mathrm{pH} 7.5$, containing $1 \%$ Triton, 2 mM EGTA, $10 \mathrm{mM}$ EDTA, $100 \mathrm{mM} \mathrm{NaF}, 1 \mathrm{mM} \mathrm{Na}_{4} \mathrm{P}_{2} \mathrm{O}_{7}, 2 \mathrm{mM} \mathrm{NaVO}_{4}, 1 \mathrm{mM}$ phenylmethylsulfonyl fluoride, $25 \mathrm{mg} / \mathrm{ml}$ aprotinin, $3.5 \mathrm{mg} / \mathrm{ml}$ pepstatin A, and $25 \mathrm{mg} / \mathrm{ml}$ leupeptin). These HCC cells had been serum starved for $24 \mathrm{~h}$ followed by the addition of insulin or IGF-1. Cell lysates containing $100 \mu \mathrm{g}$ of total protein were electrophoresed through SDS-polyacrylamide gels and proteins were transferred onto Immobilon-P membranes (Millipore Corp., Bedford, MA) followed by immunoblot analysis. Immunodectection was performed using specific antibodies and proteins revealed by the ECL system (Amersham Corp., Arlington Heights, IL). For immunoprecipitation studies, cell lysates containing $500 \mu \mathrm{g}$ of protein were incubated with specific antibodies and precipitated with protein A-agarose beads. The immunoprecipitants were subjected to SDS-polyacrylamide gel electrophoresis and proteins detected with specific antibodies.

Mitogenic and anchorage independent growth assays. HCC cells transfected with the various IRS- 1 constructs were plated at a concentration of $1 \times 10^{5}$ cells in 24 -well plates and $24 \mathrm{~h}$ later the medium was replaced with DME containing $0.25 \%$ FBS. Cells were incubated with or without $100 \mathrm{nM}$ insulin or $100 \mathrm{ng} / \mathrm{ml} \mathrm{IGF-1} \mathrm{additions} \mathrm{for} 18 \mathrm{~h}$ followed by pulse labeling with $1 \mathrm{mCi} / \mathrm{ml}\left[{ }^{3} \mathrm{H}\right]$ thymidine in $\mathrm{DME}$ for $3 \mathrm{~h}$. The labeled cells were washed, solubilized in $1 \mathrm{ml}$ of PBS and $0.1 \%$ SDS and TCA was added to a final concentration of $10 \%$. The TCA insoluble pellet was solubilized in $1 \mathrm{~N} \mathrm{NaOH}$, neutralized with $\mathrm{HCl}$ and the amount of $\left[{ }^{3} \mathrm{H}\right]$ thymidine incorporated into DNA determined by liquid scintillation counting.

The ability of transfected cells to exhibit anchorage-independent growth was determined by plating $1 \times 10^{3}$ cells in DME containing $10 \%$ FBS and $0.4 \%$ soft agar (FMC Bioproducts, Rockland, ME) and overlaid on a bottom agar containing medium consisting of DME, $10 \%$ FBS and $0.53 \%$ agar. Anchorage-independent growth of the parental and cloned stable transfectant cell lines was assessed by counting the numbers of colonies formed in soft agar $2 \mathrm{wk}$ after seeding.

Tumor formation in nude mice. To investigate tumorigenicity in nude mice, $1 \times 10^{7}$ parental (mock plasmid transfected DNA) and $\Delta \mathrm{C}$ - hIRS-1 FOCUS HCC cell clones $\mathrm{c} 1$ and $\mathrm{c} 2$ in $0.1 \mathrm{ml}$ PBS were injected subcutaneously into the back of nude mice as previously described (25). Nude mice were observed for tumor formation over a 4 -wk period. If no tumor formation was apparent at $28 \mathrm{~d}$, mice were observed for another 3 mo.

MAPK and PI3K assays. Insulin or IGF-1-induced MAPK and PI3K activation was measured using cell lysates derived from transfected cells that had been prior incubated with or without $100 \mathrm{nM}$ insulin or $100 \mathrm{ng} / \mathrm{ml} \mathrm{IGF-1} \mathrm{for} 10 \mathrm{~min}$ after a 24 -h period of serum starvation. MAPK enzymatic activity was measured according to a previously described method (13). In brief, cell lysates with or without IGF-1 stimulation were electrophoresed through SDS-polyacrylamide gels containing $0.5 \mathrm{mg} / \mathrm{ml}$ MBP. The SDS was removed from the gels by washing with $20 \%$ 2-propanol in $50 \mathrm{mM}$ Tris- $\mathrm{HCl}(\mathrm{pH} 8.0)$ for $1 \mathrm{~h}$ and then $50 \mathrm{mM}$ Tris- $\mathrm{HCl}(\mathrm{pH} 8.0)$ containing $5 \mathrm{mM}$ 2-mercaptoethanol for an additional $1 \mathrm{~h}$ at $20^{\circ} \mathrm{C}$. After the enzyme in the gels was denatured by treatment with $6 \mathrm{M}$ guanidine $\mathrm{HCl}$ and $50 \mathrm{mM}$ Tris- $\mathrm{HCl}(\mathrm{pH} 8.0)$ for $1 \mathrm{~h}$ at $20^{\circ} \mathrm{C}$ and renatured in $50 \mathrm{mM}$ Tris- $\mathrm{HCl}$ ( $\mathrm{pH} 8.0$ ) containing $0.04 \%$ Tween- 40 and $5 \mathrm{mM}$ 2-mercaptoethanol, the gel was preincubated in kinase buffer ([40 $\mathrm{mM}$ Hepes $\{\mathrm{ph} \mathrm{8.0 \} ],}$ $2 \mathrm{mM}$ dithiothreitol, $0.1 \mathrm{mM}$ EGTA, $20 \mathrm{mM} \mathrm{MgCl}$ ) for $1 \mathrm{~h}$ at $25^{\circ} \mathrm{C}$. Phosphorylation of MBP was performed by incubation of the gel with kinase buffer containing $25 \mu \mathrm{Ci}$ of $\left[\gamma^{32} \mathrm{P}\right]$ ATP (Dupont, Wilmington, $\mathrm{DE})$ for $1 \mathrm{~h}$ at $25^{\circ} \mathrm{C}$. The gel was washed in $5 \%(\mathrm{wt} / \mathrm{vol}) \mathrm{TCA}$ solution containing $1 \%$ sodium pyrophosphate and MAPK induced phosphorylation of MBP was determined by autoradiography.

PI3 kinase assay. An assay for PI3K activity was performed as previously described (28). Briefly, $500 \mu \mathrm{g}$ of cell lysate was immunoprecipitated with polyclonal antibodies against the p85 subunit of PI3K followed by incubation with protein A-Sepharose beads. The immunoprecipitates were washed twice with cell lysis buffer, once with $1 \%$ NP-40-PBS, once with $100 \mathrm{mM}$ Tris- $\mathrm{HCl}$ (pH 7.4) containing $0.5 \mathrm{M} \mathrm{LiCl}$, and twice with $10 \mathrm{mM}$ Tris- $\mathrm{HCl}$ containing $100 \mathrm{mM} \mathrm{NaCl}$. Samples were preincubated with a phosphoinosital (PI) solution (1 $\mathrm{mg}$ of sonicated PI, $50 \mathrm{mM}$ Hepes, $1 \mathrm{mM}$ EGTA, $1 \mathrm{mM}$ sodium phosphate) and then reacted with $1 \mu \mathrm{Ci}$ of $\left[\gamma^{-32} \mathrm{P}\right] \mathrm{ATP}, 50 \mathrm{mM}$ ATP and $10 \mathrm{mM} \mathrm{MgCl}$ for $10 \mathrm{~min}$. After termination of the reaction with $\mathrm{HCl}$ and $\mathrm{CHCl}_{3} /$ methanol mixture, lipid phosphorylation was analyzed by thin-layer chromatography on silica gel plates coated with $1 \%$ potassium oxalate followed by autoradiography. 


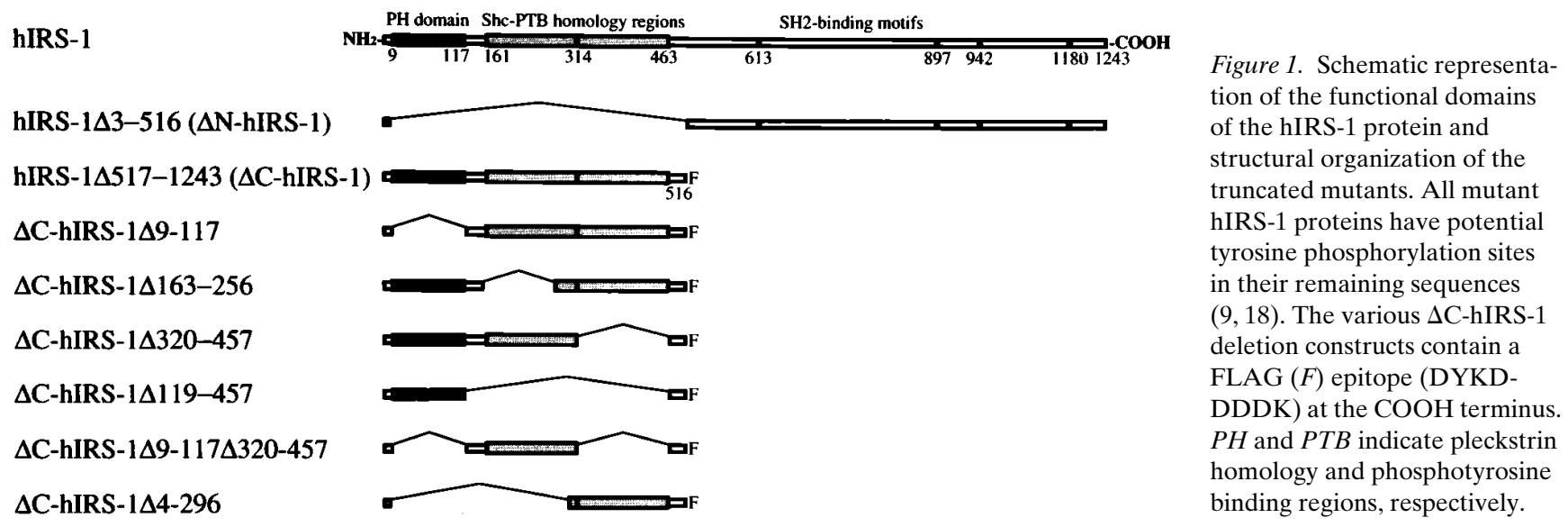

\section{Results}

The $\mathrm{NH}_{2}$ terminus of hIRS-1 is required for its tyrosyl phosphorylation in HCC cells. To determine the essential region of hIRS-1 required for TP in FOCUS HCC cells, $\mathrm{NH}_{2}$-terminal (hIRS-1 $\Delta 3$-516: $\Delta$ N-hIRS-1) and $\mathrm{COOH}$-terminal truncated mutants of hIRS-1 containing a FLAG epitope (hIRS-1 $\Delta 517$ 1243: $\Delta$ C-hIRS-1) were constructed (Fig. 1) and transiently transfected into FOCUS cells. Both mutants proteins have numerous potential TP sites in their remaining sequences $(9,18)$. Fig. $2 A$ demonstrates that following transfection of hIRS-1 $\Delta 3$ 516 and hIRS-1 $\Delta 517-1243$ constructs, the mutant proteins were expressed with the predicted molecular size as determined by a COOH-terminal specific antibody (left) and antiFLAG antibody (right). However, insulin stimulation will only TP the hIRS-1 $\Delta 517-1243$ and not the hIRS-1 $\Delta 3-516$ protein (Fig. $2 B$ ) in constructs made both with and without the FLAG epitope by direct Western blot analysis. Tyrosyl phosphorylation of the $180-190-\mathrm{kD}$ endogenous hIRS-1 protein and the $95 \mathrm{kD} \beta$ subunit of the insulin receptor was also apparent in the transfected FOCUS HCC cells after insulin stimulation. In addition, TP of hIRS-1 $\Delta 517-1243$ was also apparent in another transiently transfected HepG2 HCC cell line (Fig. 2 C). These results demonstrate that the $\mathrm{NH}_{2}$ terminus (1-516) was required for insulin stimulated TP of IRS-1 in both HCC cell lines.

Tyrosyl phosphorylation of $\Delta C-h I R S-1$ requires the first PTB domain. The $\mathrm{NH}_{2}$ terminus of hIRS-1 is composed of three functional domains; a pleckstrin homology $(\mathrm{PH})$ and two regions homologous for PTB. To address the role of these regions of the hIRS-1 molecule in the tyrosyl phosphorylation of $\Delta \mathrm{C}$-hIRS-1, constructs containing sequential truncations of these domains were prepared as shown in Fig. 1. FOCUS cells were stable transfected with each mutant construct several times and two to four clones were established under neomycin selection conditions. Each mutant protein has potential TP sites in the remaining sequences $(9,18)$. Starting from the parent $\Delta$ C-hIRS-1 molecule, Fig. $3 A$ (lane 3 ) illustrates that, as expected, progressive truncation of these regions (lanes 4-9) reduced the size of the expressed protein. As demonstrated by
A.

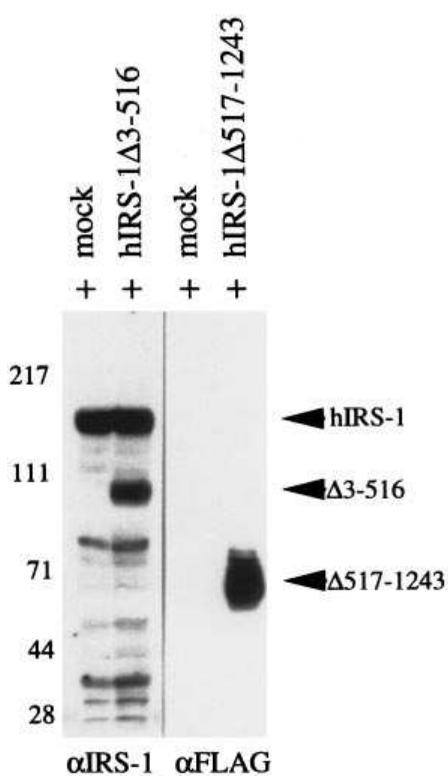

B.

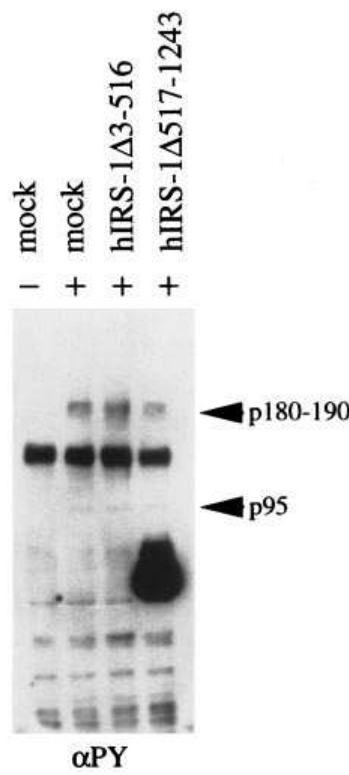

C.

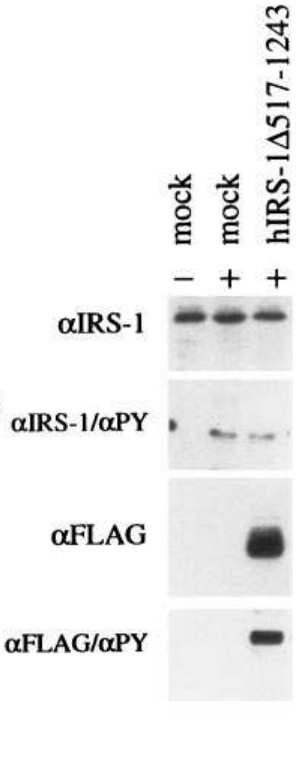

Figure 2. Transient expression of the hIRS-1truncated mutants in $\mathrm{HCC}$ cells with $(+)$ or without (-) $100 \mathrm{nM}$ insulin stimulation. (A) Cellular expression in transfected FOCUS cells of $\mathrm{NH}_{2-}$ terminal (hIRS-1 $\Delta 3-516$ ) and $\mathrm{COOH}$-terminal deletion mutants (hIRS-1 $\Delta 517-1243$ ) as identified by anti-COOH-terminal specific hIRS-1 $(\alpha I R S-1)$ and anti-FLAG M2 antibodies $(\alpha F L A G)$, respectively. Mock indicates transfection with empty plasmid vector. $(B)$ Tyrosyl phosphorylation $(T P)$ of hIRS-1 $\Delta 3-516$ hIRS-1 and $\Delta 517-1243$ constructs as detected by an antiphosphotyrosine antibody $(\alpha P Y)$. Note the TP of hIRS-1 $\Delta 517-1243$ was prominent in FOCUS cells. $(C)$ Analysis of endogenous expression of hIRS-1 ( $\alpha I R S-1)$, TP of hIRS-1 ( $\alpha I R S-1 / \alpha P Y)$, and expression $(\alpha F L A G)$ and TP $(\alpha F L A G / \alpha P Y)$ of the $\Delta 517-1243 \mathrm{COOH}$-terminal deletion mutant transiently transfected in HepG2 cells. We used nonrelevant monoclonal and polyclonal antibodies as controls for specific immunoprecipitation of the above hIRS-1 mutant proteins. 

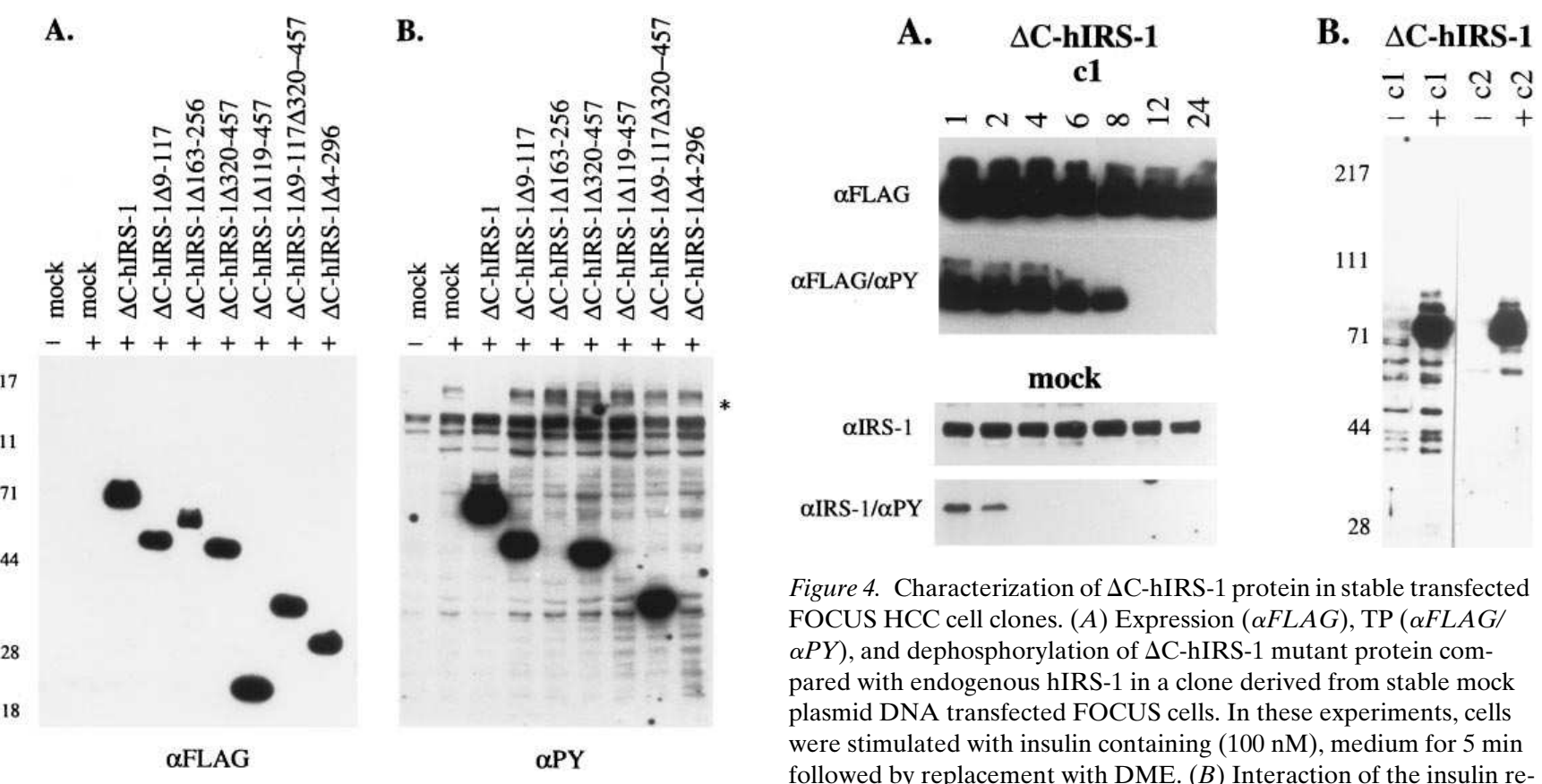

Figure 4. Characterization of $\Delta \mathrm{C}$-hIRS-1 protein in stable transfected FOCUS HCC cell clones. ( $A$ ) Expression $(\alpha F L A G)$, TP $(\alpha F L A G /$ $\alpha P Y$ ), and dephosphorylation of $\Delta$ C-hIRS-1 mutant protein compared with endogenous hIRS-1 in a clone derived from stable mock plasmid DNA transfected FOCUS cells. In these experiments, cells were stimulated with insulin containing $(100 \mathrm{nM})$, medium for $5 \mathrm{~min}$ followed by replacement with DME. (B) Interaction of the insulin receptor with $\Delta$ C-hIRS-1 protein in two stable clones ( 1 and $c 2)$. Cell lysates derived from each clone were stimulated with $(+)$ or without $(-)$ insulin and immunoprecipitated using an anti-insulin receptor antibody followed by immunoblotting with an anti-FLAG antibody $(\alpha I R / \alpha F L A G)$ to detect the $\Delta \mathrm{C}$-hIRS-1 mutant protein in the immunoprecipitate. as detected by anti-FLAG M2 antibody $(\alpha F L A G)$. (B) TP $\triangle \mathrm{C}$-hIRS-1 and its derivatives in stable transfected FOCUS HCC cells. Note that not all COOH-terminal truncated hIRS-1 mutant proteins are TP after insulin stimulation. Insulin induced TP of $\Delta C$-hIRS-1 was associated with reduction of TP of endogenous hIRS-1. Mock indicates transfection with empty plasmid vector.

the direct antiphosphotyrosine $(\alpha P Y)$ immunoblot shown in Fig. $3 B$, the $\Delta$ C-hIRS-1 (lane 3 ), $\Delta$ C-hIRS-1 $\Delta$ 9-117 (lane 4), $\Delta$ C-hIRS-1 $\Delta 320-457$ (lane 6), and $\Delta$ C-hIRS-1 $\Delta 9-117 \Delta 320-457$ (lane 8 ) mutant proteins were TP after insulin stimulation in FOCUS cells. In contrast, $\Delta \mathrm{C}$-hIRS-1 $\Delta 163-256$ (lane 5), $\Delta \mathrm{C}$ hIRS-1 $\Delta 119-457$ (lane 7), and $\Delta$ C-hIRS-1 $\Delta 4$-296 (lane 9) mutant proteins were not tyrosyl phosphorylated to any appreciable extent. The mean transfection efficiencies of the various plasmid constructs were essentially equal and produced G418 resistant colonies in the range of 53.7-55.3 colonies per microgram of DNA in three independent experiments. There was no change in the level of expression of the insulin receptor or endogenous hIRS-1 protein in all stable transfected and cloned cell lines (data not shown). These studies demonstrate that the most proximal PTB domain was required for TP of $\Delta$ C-hIRS-1 in FOCUS HCC cells.

$\Delta C$-hIRS-1 inhibits insulin/IGF-1-induced tyrosyl phosphorylation of endogenous $h I R S-1$. After insulin stimulation, the $180-190 \mathrm{kD}$ endogenous hIRS-1 protein is TP in mock-plasmid DNA transfected FOCUS HCC cells (Fig. $2 B$, lanes 1 and 2 and Fig. $3 B$, lanes 1 and 2). In FOCUS HCC cells stable transfected with $\Delta$ C-hIRS-1, however, the TP of endogenous hIRS-1 was substantially decreased whereas the expressed $\Delta$ C-hIRS-1 mutant protein becomes highly tyrosyl phosphorylated (Fig. $3 B$, lane 3 ). It has been previously established that endogenous IRS-1 becomes rapidly dephosphorylated upon insulin deprivation in vitro (29). Similarly, endogenous hIRS-1 was rapidly

dephosphorylated with $2 \mathrm{~h}$ in insulin-derived mock plasmid DAN tranfected FOCUS cells as shown in Fig. 4 A (bottom). However, the tyrosyl phosphorylated $\Delta$ C-hIRS-1 protein was not dephosphorylated as rapidly as endogenous hIRS-1 and high levels of phosphorylation were observed after $8 \mathrm{~h}$ of insulin deprivation (Fig. $4 A$, top), a phenomenon that may be due, in part, to the fact that the exogenous mutant protein is highly overexpressed relative to the endogenous IRS-1 molecule. In addition, the $\Delta \mathrm{C}$-hIRS-1 protein coimmunoprecipitated with the $\beta$ subunit of the insulin receptor (Fig. $4 B$ ), suggesting that the mutant molecule will bind to and occupy the insulin receptor. Other tyrosyl phosphorylated mutant proteins were found not to coimmunoprecipate with the $\beta$ subunit of the insulin receptor (data not shown). This dominant negative effect on TP of endogenous hIRS-1 was not observed with stable cloned cell lines illustrated in Fig. $3 B$, lanes $4-9$ expressing other hIRS-1 mutant proteins. Finally, two to four clones derived from each stable expressing mutant hIRS-1 construct were studied and the same results were obtained.

Another protein such as Shc also functions as an intracellular substrate for EGF, insulin, and IGF-1 cell surface receptors (30-32). Insulin and IGF-1 additions will stimulate TP of Shc protein in mock-plasmid DNA transfected FOCUS cells (Fig. 5). In contrast, stable $\Delta \mathrm{C}$-hIRS-1 transfected FOCUS cell clones (c1 and c2) demonstrate a striking suppression of insulin/IGF-1 induced TP of Shc (Fig. $5 \mathrm{~A}$ ). However, expression of $\Delta \mathrm{C}$ hIRS-1 protein did not affect TP of Shc induced by EGF stimulation (Fig. $5 \mathrm{~A}$ ). Thus, $\Delta \mathrm{C}$-hIRS-1 protein overexpression in HCC cells will inhibit insulin and/or IGF-1-induced TP of endogenous cellular substrates other than hIRS-1. Similar findings were observed with a c3 $\Delta$-hIRS-1 clone (data not shown). 


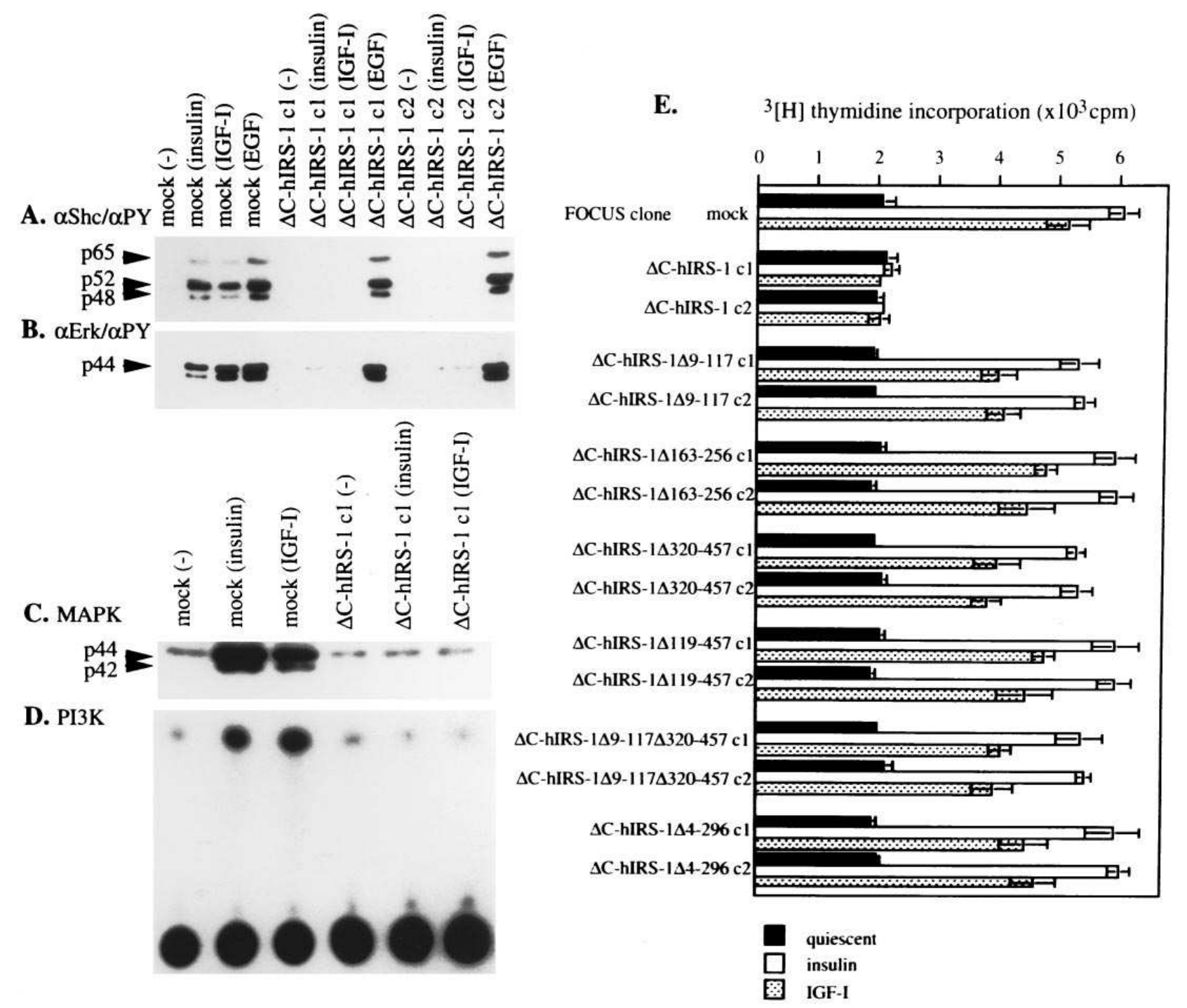

Figure 5. Tyrosyl phosphorylation of Shc and Erk1 proteins in $\Delta$ C-hIRS-1 stable transfected FOCUS HCC clones $(c 1$ and $c 2)$ as compared with a mock plasmid DNA transfected clone $(A)$. Cell lysates were obtained from each clone after stimulation with $100 \mathrm{nM}$ insulin, $100 \mathrm{ng} / \mathrm{ml}$ IGF-1, or $100 \mathrm{ng} / \mathrm{ml}$ EGF for $10 \mathrm{~min}$ and then analyzed for TP of Shc by immunoprecipitation and by immunodetection $(\alpha S h c / \alpha P Y)$. (B) Analysis of TP $(\alpha E r k / \alpha P Y)$ of Erk1 ( $p 44)$ and Erk2 ( $p 42)$ after insulin, IGF-1, and EGF stimulation. Note that $\Delta \mathrm{C}$-hIRS-1 protein blocks TP of endogenous Shc and Erk1 and Erk2 proteins after insulin and IGF-1 stimulation but not after EGF stimulation. Measurement of MAPK $(C)$ and PI3K activity $(D)$ in $\triangle$ C-hIRS-1 transfected FOCUS cells (clone 1) following stimulation with $100 \mathrm{nM}$ insulin or $100 \mathrm{ng} / \mathrm{ml} \mathrm{IGF-1,} \mathrm{compared} \mathrm{with} \mathrm{a} \mathrm{mock} \mathrm{plas-}$ mid DNA stable transfected FOCUS HCC cell clone. $(E)$ Measurement of ${ }^{3}[\mathrm{H}]$ thymidine incorporation into DNA of clones stable transfected with $\Delta$ C-hIRS-1 mutant constructs. Cell lines were stimulated with $100 \mathrm{nM}$ insulin or $100 \mathrm{ng} / \mathrm{ml}$ IGF-1 and results compared with a mock-plasmid DNA transfected cell line.

Tyrosyl phosphorylation of endogenous hIRS-1 induced by insulin and IGF-1 leads to the activation of downstream molecules involved in the signal transduction cascade such as MAPK (Fig. 5 B). In this regard, subsequent MAPK (Fig. $5 C$ ), and PI3K activation (Fig. $5 \mathrm{D}$ ) induced by insulin stimulation were found to be substantially reduced to levels found in noninsulin-stimulated cells in $\Delta \mathrm{C}$-hIRS-1 stable transfected FOCUS cell clones.

$\left[{ }^{3} \mathrm{H}\right]$ thymidine incorporation into DNA was measured in stable transfected FOCUS cell lines to assess the effects of hIRS-1 mutant constructs on insulin and IGF stimulation of DNA synthesis. As expected, $\left[{ }^{3} \mathrm{H}\right]$ thymidine incorporation was increased approximately threefold in mock plasmid DNA transfected cells after insulin/IGF-1 stimulation. However, there was a significant reduction in DNA synthesis almost to the level observed in quiescent cells in each of the two $\Delta \mathrm{C}$ hIRS-1-transfected clones (Fig. 5 E). Stable cloned FOCUS cell lines transfected with the other mutant constructs had substantially less and more variable inhibition of $\left[{ }^{3} \mathrm{H}\right]$ thymidine incorporation into DNA. Finally, detailed growth curves were performed on the cell lines presented in Fig. $5 \mathrm{E}$. We found that only the $\Delta \mathrm{C}$-hIRS-1 stable-transfected cloned c1 and c2 grew at a substantially slower rate than cell lines stably transfected with the other truncated hIRS-1 mutant constructs which grew at a rate similar to mock DNA transfected FOCUS cells (data not shown). 
Table I. Anchorage-independent Growth of Transfected FOCUS HCC Cells

\begin{tabular}{|c|c|}
\hline Clone & $\begin{array}{l}\text { Efficiency of colony formation } \\
\text { in soft agar (\%) }\end{array}$ \\
\hline Mock & $7.2 \pm 0.5$ \\
\hline$\Delta \mathrm{C}$-hIRS-1 c1 & $0.2 \pm 0.1$ \\
\hline$\Delta$ C-hIRS-1 c2 & $0.1 \pm 0.1$ \\
\hline$\Delta$ C-hIRS- $1 \Delta 9-117 \mathrm{c} 1$ & $4.3 \pm 1.1$ \\
\hline$\Delta \mathrm{C}$-hIRS-1 $\Delta 9-117 \mathrm{c} 2$ & $3.6 \pm 0.7$ \\
\hline$\Delta \mathrm{C}$-hIRS-1 $\Delta 163-256 \mathrm{c} 1$ & $6.8 \pm 1.0$ \\
\hline$\Delta$ C-hIRS- $1 \Delta 163-256$ c2 & $7.2 \pm 0.8$ \\
\hline$\Delta$ C-hIRS-1 $\Delta 320-457 \mathrm{c} 1$ & $4.0 \pm 0.6$ \\
\hline$\Delta$ C-hIRS- $1 \Delta 320-457$ c2 & $3.1 \pm 0.3$ \\
\hline$\Delta$ C-hIRS-1 $\Delta 119-457 \mathrm{c} 1$ & $8.2 \pm 1.1$ \\
\hline$\Delta$ C-hIRS-1 $\Delta 119-457$ c2 & $7.6 \pm 1.3$ \\
\hline$\Delta$ C-hIRS-1 $\Delta 9-117 \Delta 320-457 \mathrm{c} 1$ & $5.1 \pm 0.5$ \\
\hline$\Delta$ C-hIRS-1 $\Delta 9-117 \Delta 320-457$ c2 & $4.2 \pm 0.4$ \\
\hline$\Delta$ C-hIRS-1 $\Delta 4-296 \mathrm{c} 1$ & $6.6 \pm 0.9$ \\
\hline$\Delta$ C-hIRS-1 $\Delta 4-296$ c2 & $7.1 \pm 0.8$ \\
\hline
\end{tabular}

Values for growth in soft agar represent averages and standard deviation of colony formation normalized to total cell number in each well. These data were obtained from duplicate experiments.
Expression of the $\Delta C$-hIRS-1 protein changes the characteristics of the malignant phenotype. The FOCUS cell line was initially isolated and cloned from a poorly differentiated hepatitis B virus-positive HCC tumor and such cells exhibit the characteristics of the malignant phenotype (25) including anchorage-independent cell growth (33). As shown in Table I, mock plasmid DNA transfected FOCUS cells will form colonies in soft agar. However, individual clones derived from $\Delta C$ hIRS-1 transfected FOCUS cells demonstrate very low efficiency of colony formation in soft agar and indicate the loss of anchorage-independent cell growth. All cloned cell lines transfected with other mutant hIRS- 1 constructs retain the ability of anchorage independent growth to various degrees.

Mock plasmid DNA-transfected FOCUS cells are poorly differentiated and exhibit a flattened large irregular shape, multiple mitotic figures, and pleomorphic nuclei with prominent nucleoli (Fig. $6 \mathrm{~A}$ ). FOCUS cells grow rapidly without contact inhibition and form multi-layered structures upon reaching confluence (Fig. $6 \mathrm{D}$ ). Stable transfection of $\Delta \mathrm{C}$ hIRS-1 substantially alters the morphologic appearance of FOCUS cells. Cloned cell lines (c1 and c2) exhibit a differentiated pattern of growth including sinusoid formation and have an appearance reminiscent of primary hepatocytes in culture (Fig. 6, $B$ and $C$ ) (34). In addition, the $\Delta$ C-hIRS-1-transfected

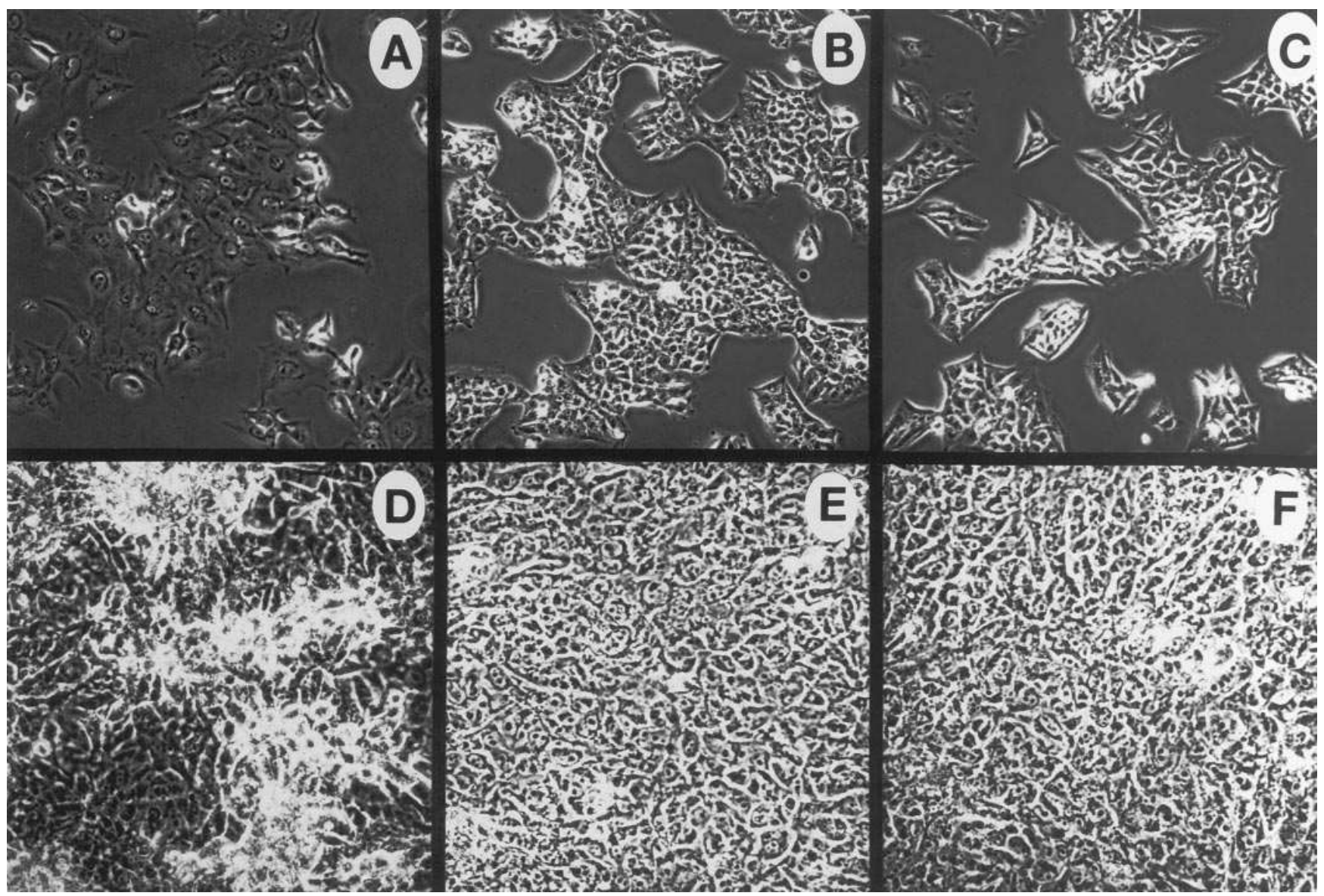

Figure 6. Morphologic appearance of $\triangle$ C-hIRS-1 and mock plasmid DNA stable transfected FOCUS HCC cells clones. Panels $A(\times 25)$ and $D$ $(\times 100)$ are mock DNA-transfected cells. Panels $B$ and $C$ represent two $\Delta$ C-hIRS-1 (c1 and c2) transfected FOCUS HCC clones. Note that these cells have morphologic features similar to primary hepatocytes in culture as illustrated by a sinusoidal pattern of growth, polygonal shape, and contact inhibition as shown in $E$ and $F(\times 100)$. 
A.

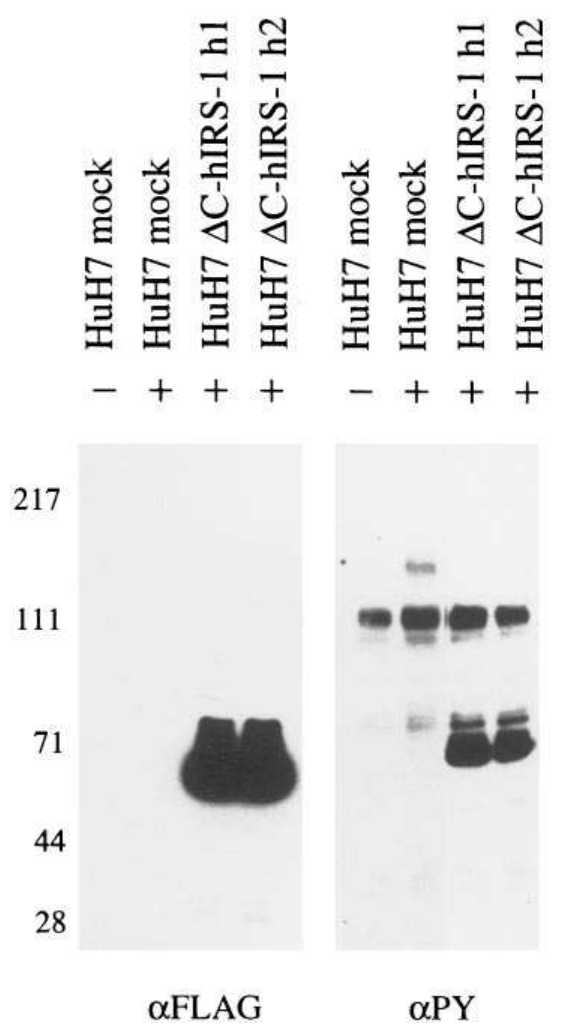

B.

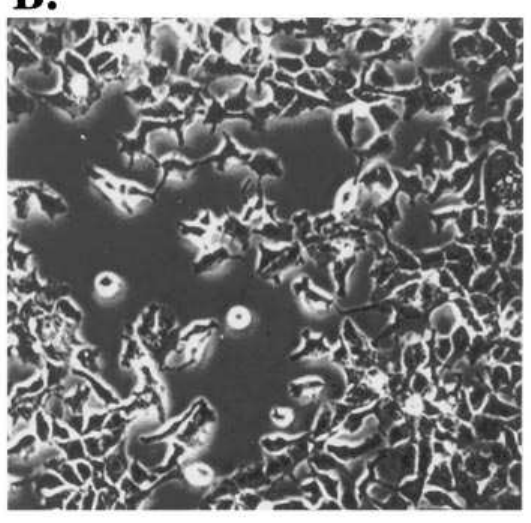

D.

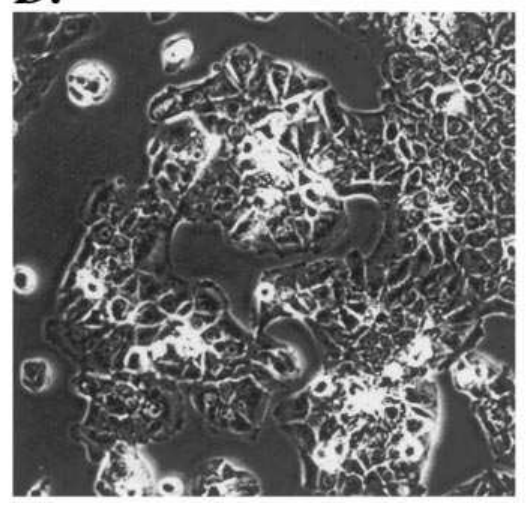

C.

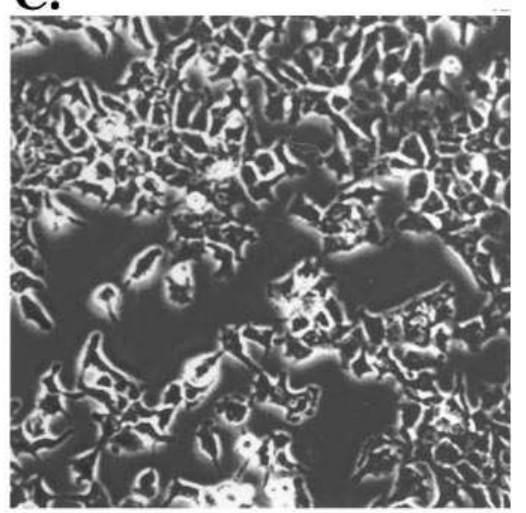

E.

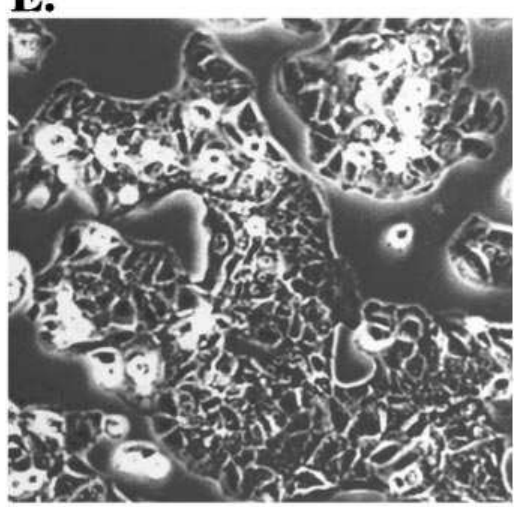

Figure 7. HuH-7 HCC cells stable transfected with $\Delta$ C-hIRS-1 (clones h1 or h2) with (+) or without (-) IGF-1 (100 ng/ml) stimulation. $(A)$ Western blot analysis demonstrating expression and TP of $\Delta$ C-hIRS-1 protein. $(B-E)$ Morphologic appearance of the transfected HuH-7 HCC cells $(\times 25)$. Cellular morphology of mock-plasmid DNA transfected HuH-7 cells under serum-free $(B)$ or $10 \%$ FBS conditions $(C)$. Pattern of growth of $\Delta \mathrm{C}$-hIRS-1 transfected HuH-7 cells (clone H1:D, clone h2:E).

cells are much smaller in size and have a polygonal morphology with normal appearing nuclei. FOCUS cells expressing $\Delta$ C-hIRS-1 now exhibit contact inhibition of cell growth (Fig. 6, $E$ and $F$ ).

A similar alteration of phenotype was also observed in HuH-7 cells transfected stably with $\Delta$ C-hIRS-1 (Fig. 7). HuH-7 cells may be grown under serum-free conditions and were derived from a human tumor not related to chronic hepatitis $\mathrm{B}$ virus infection (26). Fig. $7 \mathrm{~A}$ demonstrates expression (left) and tyrosyl phosphorylation (right) of $\Delta \mathrm{C}$-hIRS-1 protein in two clones of stable transfected HuH-7 cells (h1 and h2) after stimulation by IGF-1 (100 ng/ml). Expression of $\Delta$ C-hIRS-1 inhibits IGF-1 induced tyrosyl phosphorylation of endogenous hIRS-1 (Fig. 7 A, lanes 3 and 4, left). Mock plasmid DNA transfected $\mathrm{HuH}-7$ cells have a pleomorphic and fibroblastoid appearance in both serum free or medium containing $10 \%$ FBS (Fig. 7, $B$ and $C$ ). The $\Delta$ C-hIRS-1 transfected HuH-7 clones (h1 and h2), however, demonstrate a differentiated polygonal cellular morphology and form flat sheets of cells exhibiting the phenomenon of contact inhibition. Such $\Delta$ C-hIRS-1expressing cells also develop a sinusoidal pattern of growth reminiscent of adult hepatocytes in culture (Fig. 7, $D$ and $E$ ).

Finally, the ability of parental FOCUS and two $\Delta$ C-hIRS-1 stable-transfected cloned cell lines ( $\mathrm{c} 1$ and $\mathrm{c} 2$ ) to form solid tumors in nude mice was assessed (25). After the subcutaneous injection of $1 \times 10^{7}$ mock plasmid transfected FOCUS cells into nude mice, there was rapid tumor formation at the injection site and tumors reached a mean size of $2.5 \mathrm{~cm}$ within $28 \mathrm{~d}$ in 9 of 10 injected nude mice. In contrast, none of the mice injected with the c1 and c $2 \Delta \mathrm{C}$-hIRS-1 clones developed tumors (Table II) even after three additional months of observation.

\section{Discussion}

The hIRS-1 protein serves as the main intracellular substrate for receptor tyrosine kinase activity of the insulin/IGF-1 receptors and sends downstream signals by interaction with various $\mathrm{SH} 2$-containing molecules at specific motifs located in the $\mathrm{COOH}$-terminal region of the molecule (9). Our study demonstrates that the $\mathrm{NH}_{2}$-terminal region of hIRS-1 mutant protein was essential for TP induced by insulin and IGF-1 signals in

Table II. Tumor Formation of Transfected FOCUS HCC Cells

\begin{tabular}{cc}
\hline Clone & Tumors/mice \\
\hline Mock plasmid & $9 / 10$ \\
$\Delta$ C-hIRS-1 c1 & $0 / 9$ \\
$\Delta$ C-hIRS-1 c2 & $0 / 9$ \\
\hline
\end{tabular}

Tumorigenicity was determined by subcutaneous injection of $1 \times 10^{7}$ cells and measurement of tumor size at $4 \mathrm{wk}$. 
HCC cells. Impairment of $\Delta$ C-hIRS-1 tyrosyl phosphorylation was produced by a deletion of the most proximal $\mathrm{NH}_{2}$-terminal PTB domain indicating that this region was indispensable for TP induced by ligand stimulation. Recent reports have demonstrated that the PTB domain of the Shc protein recognizes a NPXY motif on various receptors with tyrosine kinase activity $(35,36)$. One NPXY motif has been identified in the juxtamembrane region of both the insulin and IGF-1 receptors. This motif has been found to interact with the PTB domain by the yeast two hybrid system (19) and the same region may be a functional target for the PTB domains of endogenous IRS- 1 as well as for the $\Delta \mathrm{C}$-hIRS- 1 mutant protein. In addition, another specific intracellular substrate of the insulin receptor such as 4PS/IRS-2 also contains a highly homologous region (named as IRS homology domain-2) to the first PTB domain of IRS-1 $(18,37)$.

All of these receptor substrates, therefore, may simultaneously interact with the NPXY motif of the insulin/IGF-1 receptors. In this regard, mutations of the NPXY motif on receptors diminishes downstream effects of insulin/IGF-1 signals such as inhibition of Ras activation by altering the interaction of receptors with IRS-1 and Shc proteins $(19,38)$. The overexpressed $\Delta$ C-hIRS-1 mutant protein will bind to the insulin receptor (Fig. $4 \mathrm{~B}$ ) and substantially inhibit TP of endogenous intracellular substrates in HCC cells (Fig. $3 B$, lane 3 and Fig. 5 $A)$. It will be important to clarify the stoichiometry of this interaction in future studies. This potent dominant negative effect inhibits insulin/IGF-1 signals principally because the mutant protein binds with high avidity to these receptors, subsequently becomes highly tyrosyl phosphorylated and inhibits TP of endogenous substrates in HCC cells. The insulin/ IGF-1 signals transmitted to downstream molecules are blocked since there will be no interaction of the $\Delta \mathrm{C}$-hIRS- 1 mutant protein with known SH2-containing molecules such as Syp tyrosine phosphatase, Grb2 adapter protein, and p85 subunit of $\mathrm{PI} 3 \mathrm{~K}$ since their binding motifs have been deleted from the $\mathrm{COOH}$-terminal region of the molecule.

The mechanisms of this dominant negative effect were further studied with respect to the functional domains of the $\Delta \mathrm{C}$ hIRS-1 molecule. The dominant negative properties of $\Delta \mathrm{C}$ hIRS-1 were found to be abolished by deletion of either the PH or both PTB domains (Figs. 3 and 5). Recently, Myers et al. revealed that the $\mathrm{PH}$ domain enhanced the binding of IRS- 1 to the insulin receptor (39). Furthermore, the $\mathrm{PH}$ domain is involved in the IRS-1 interaction with Janus tyrosine kinase Tyk-2 (10). Although other functions of $\mathrm{PH}$ domain remain to be clarified, the demonstration of an interaction with the $G$ protein ( $\alpha \beta$ subunits) (40) and phospholipids (41) suggests that this region may play an additional role of linking IRS-1 with other signal transduction pathways. In the present investigation, the more proximal PTB domain was shown to be an essential region with respect to producing a dominant negative effect since deletion of this domain allowed TP of endogenous substrates necessary to transmit the insulin and IGF-1 signals within the cell.

Our studies demonstrate that expression of $\Delta \mathrm{C}$-hIRS-1 protein will reverse the malignant phenotype of HCC cells (Tables I and II), principally because of dominant negative effects exerted on insulin/IGF-I (and perhaps others) mediated signal transduction pathways. Indeed, as shown in Figs. 6 and 7, the morphologic appearance of both $\Delta \mathrm{C}$-hIRS-1-transfected $\mathrm{HCC}$ cell lines is quite similar to differentiated adult hepato- cytes grown in primary culture (34). It is also of interest that IRS-1 plays a potential role in various other cytokine signaling pathways that may be involved in cell proliferation such as interleukins, integrins, and growth hormone in addition to insulin and IGF-1 $(7,11,42)$. The morphologic changes induced by $\Delta$ C-hIRS-1 overexpression cannot be reproduced in human HCC cells by either ligand (insulin and IGF-1) deprivation or matrix supplementation (43). The function of $\Delta \mathrm{C}$-hIRS-1 with respect to reversing the transformed phenotype may involve inhibition of multiple intracellular signaling pathways, some of which contribute either to the initiation or maintenance of the transformed phenotype. Further analysis of other intracellular molecule(s) associated with $\Delta \mathrm{C}$-hIRS-1 should provide clues regarding the molecular mechanism(s) of hepatocarcinogenesis.

It has been well recognized that growth factors and their receptors are important in the development of human malignancy (44). Tyrosine phosphorylation of intracellular substrates induced by growth factor receptor tyrosine kinases is one the key intracellular mechanisms to initiate signal transduction related to growth by promoting the binding of molecules such as IRS-I to Src-homology-2 (SH2) or PTB domains of other signaling molecules (36). Binding to phosphotyrosine sites by $\mathrm{SH} 2$-containing proteins may affect the function of these molecules through direct stimulation of enzymatic activity (45), relocation within the cytoplasm (46), and enhanced $\mathrm{TP}$ of other growth-related proteins (47). In this regard, persistent activation of the MAPK cascade by gain of function mutations has been found sufficient to transform mammalian cells $(48,49)$. We have also found that overexpression of hIRS-1induced cellular transformation and liver associated with constitutive activation of the MAPK cascade $(22,23)$.

Human HCC is one of the most ubiquitous tumors (approximately one million cases per year) in the world today and has a five year survival rate of $<5 \%$ (1). The $\Delta$ C-hIRS- 1 mutant protein has been shown here to inhibit tumor cell growth and reverse the malignant characteristics of human HCC cells to a more differentiated phenotype. One salient issue to be resolved with additional investigations is whether the present work is revealing a transformation mechanism that is unique to HCC cells, or whether this transformation mechanism is common to a variety of tumor cell types.

\section{Acknowledgments}

We thank Drs. Toshifumi Ito, Margherita Melegari, and Kazuyoshi Yonezawa for helpful discussions.

This work was supported by grants CA-35711 and AA-02666 from the National Institutes of Health.

\section{References}

1. Moradpour, D., and J.R. Wands. 1996. Hepatic oncogenesis. In Hepatology. 3rd edition. D. Zakim and T. Boyer, editors. W.B. Saunders, Philadelphia. 1490-1512.

2. Koch, K.S., and H.L. Leffert. 1979. Increased sodium ion influx is necessary to initiate rat hepatocyte proliferation. Cell. 18:153-163.

3. Koch, K.S., P. Shapiro, H. Skelly, and H.L. Leffert. 1982. Rat hepatocyte proliferation is stimulated by insulin-like peptides in defined medium. Biochem. Biophys. Res. Commun. 109:1054-1060.

4. Leffert, H.L., and K.S. Koch. 1977. Control of normal cell proliferation. In Growth, Nutrition \& Metabolism of Cells in Culture. Vol. 3. Rothblat, G.H. and V.J. Cristofalo, editors. Academic Press, Inc., New York. 225-294.

5. Furusaka, A., M. Nishiyama, K. Ohkawa, T. Yamori, T. Tsuruo, K. Yonezawa, M. Kasuga, S. Hayashi, and T. Tanaka. 1994. Expression of insulin re- 
ceptor substrate-1 in hepatocytes: an investigation using monoclonal antibodies. Cancer Lett. 84:85-92.

6. Nishiyama, M., and J.R. Wands. 1992. Cloning and increased expression of an insulin receptor substrate-1-like gene in human hepatocellular carcinoma. Biochem. Biophys. Res. Commun. 183:280-285.

7. Artersinger, L.S., G.W. Hsu, M.G. Myers, Jr., N. Billestrup, M.F. White, and C. Carter-Su. 1995. Growth hormone, interferon-gamma, and leukemia inhibitory factor promoted tyrosyl phosphorylation of insulin receptor substrate1. J. Biol. Chem. 270:14685-14692.

8. Guo, D., and D.B. Donner. 1996. Tumor necrosis factor promotes phosphorylation and binding of insulin receptor substrate 1 to phosphatidylinositol 3-kinase in 3T3-L1 adipocytes. J. Biol. Chem. 271:615-618.

9. Myers, M.G., Jr., X.J. Sun, and M.F. White. 1994. The IRS-1 signaling system. Trends Biochem. Sci. 19:289-293.

10. Platanias, L.C., S. Uddin, A. Yetter, S.J. Sun, and M.F. White. 1996. The type I interferon receptor mediates tyrosine phosphorylation of insulin receptor substrate 2. J. Biol. Chem. 271:278-282.

11. Welham, M.J., L. Learmonth, H. Bone, and J.W. Schrader. 1995. Interleukin-13 signal transduction in lymphohemopoietic cells. Similarities and differences in signal transduction with interleukin-4 and insulin. J. Biol. Chem. 270:12286-12296.

12. Sun, X.J., M.G. Myers, Jr., M. Miralpeix, and M.F. White. 1993. Pleiotropic insulin signals are engaged by multisite phosphorylation of IRS-1. Mol. Cell. Biol. 13:7418-7428.

13. Baltensperger, K., L.M. Kozma, A.D. Cherniack, J.K. Klarlund, A. Chawla, U. Banerjee, and M.P. Czech. 1993. Binding of ras activator son of sevenless to insulin receptor substrate-1 signaling complex. Science (Wash. DC). 260:1950-1952.

14. Kuhne, M.R., T. Pawson, G.E. Lienhard, and G.S. Feng. 1993. The insulin receptor substrate 1 associates with the SH2-containing phosphotyrosine phosphatase Syp. J. Biol. Chem. 268:11479-11481.

15. Backer, J.M., M.G. Myers, Jr., S.E. Shoelson, D.J. Chin, X.J. Sun, M. Miralpeix, P. Hu, B. Margolis, E.Y. Skolnik, J. Schlessinger, and M.F. White. 1992. Phosphatidylinositol 3'-kinase is activated by association with IRS-1 during insulin stimulation. EMBO (Eur. Mol. Biol. Org.) J. 11:3469-3479.

16. Myers, M.G., Jr., J.M. Backer, X.J. Sun, S. Shoelson, P. Hu, J. Schlessinger, M. Yoakim, B. Schaffhausen, and M.F. White. 1992. IRS-1 activates phosphatidylinositol 3 '-kinase by associating with Src homology 2 domains of p85. Proc. Natl. Acad. Sci. USA. 89:10350-10354.

17. Musacchio, A., T. Gibson, P. Rice, J. Thompson, and M. Saraste. 1993. The PH domain: a common piece in the structural patchwork of signaling proteins. Trends Biochem. Sci. 18:343-348.

18. Sun, X.J., L.M. Wang, Y. Zhang, L. Yenush, M.G. Myers, Jr., E. Glasheen, W.S. Lane, J.H. Pierce, and M.F. White. 1995. role of IRS-2 in insulin and cytokine signaling. Nature (Lond.). 377:173-177.

19. Gustafson, T.A., W. He, A. Craparo, C.D. Schaub, and T.J. O'Neill. 1995. Phosphotyrosine-dependent interaction of SHC and insulin receptor substrate 1 with the NPEY motif of the insulin receptor via a novel non-SH2 domain. Mol. Cell. Biol. 15:2500-2508.

20. Sasaki, Y., X.F. Zhang, M. Nishiyama, J. Avruch, and J.R. Wands. 1993. Expression and phosphorylation of insulin receptor substrate 1 during rat liver regeneration. J. Biol. Chem. 268:3805-3808.

21. D'Ambrosio, C., S.R. Keller, A. Morrione, G.E. Lienhard, R. Baserga, and E. Surmacz. 1995. Transforming potential of the insulin receptor substrate 1. Cell Growth \& Differ. 6:557-562.

22. Ito, T., Y. Sasaki, and J.R. Wands. 1996. Overexpression of human insulin receptor substrate 1 induces cellular transformation with activation of mitogen-activated protein kinases. Mol. Cell. Biol. 16:943-951.

23. Tanaka, S., T. Ito, and J.R. Wands. 1996. Neoplastic transformation induced by insulin receptor substrate-1 (IRS-1) overexpression requires an interaction with both Grb2 and Syp signaling molecule. J. Biol. Chem. 271:1461014616.

24. Macaulay, V.M. 1992. Insulin-like growth factors and cancer. Br. J. Cancer. $65: 311-320$.

25. He, L., K.J. Isselbacher, J.R. Wands, H.M. Goodman, C. Shih, and A. Quaroni. 1984. Establishment and characterization of a new human hepatocellular carcinoma cell line. In Vitro. (Rockville). 20:493-504.

26. Nakabayashi, H., K. Taketa, K. Miyano, T. Yamane, and J. Satao. 1982. Growth of human hepatoma cell lines with differentiated functions in chemically defined medium. Cancer Res. 42:3858-3863.

27. Kaleko, M., W.J. Rutter, and A. D. Miller. 1990. Overexpression of the human insulin-like growth factor I receptor promotes ligand-dependent neo- plastic transformation. Mol. Cell. Biol. 10:464-473.

28. Sasaki, Y., and J.R. Wands. 1994. Ethanol impairs insulin receptor substrate-1 mediated signal transduction during rat liver regeneration. Biochem. Biophys. Res. Commun. 199:403-409.

29. Kuhne, M.R., Z. Zhao, J. Rowles, B.E. Lavan, S.H. Shen, E.H. Fischer, and G.E. Lienhard. 1994. Dephosphorylation of insulin receptor substrate 1 by the tyrosine phosphorylation PTP2C. J. Biol. Chem. 269:15833-15837.

30. Pelicci, G., L. Lanfrancone, F. Grignani, J. McGlade, F. Cavallo, G Forni, I. Nicoletti, F. Grignani, T. Pawson, and P.G. Pelicci. 1992. A novel transforming protein (shc) with and $\mathrm{SH} 2$ domain is implicated in mitogenic signal transduction. Cell. 70:93-104.

31. Sasaoka, T., D.W. Rose, B.H. Jhun, A.R. Saltiel, B. Draznin, and J.M. Olefsky. 1994. Evidence for a functional role of Shc proteins in mitogenic signaling induced by insulin, insulin-like growth factor-1, and epidermal growth factor. J. Biol. Chem. 269:13689-13694.

32. Tamemoto, H., T. Kadowaki, K. Tobe, T. Yagi, H. Sakura, T. Hayakawa, Y. Terauchi, K. Ueki, Y. Kaburagi, S. Satoh, et al. 1994. Insulin resistance and growth retardation in mice lacking insulin receptor substrate-1. $\mathrm{Na}$ ture (Lond.). 372:182-186.

33. Barrett, J.C. and P.O. Ts'o. 1978. Evidence for the progressive nature of neoplastic transformation in vitro. Proc. Natl. Acad. Sci. USA. 75:3761-3765.

34. Bissell, D.M., D.M. Arenson, and J.J. Maher. 1987. Support of cultured hepatocytes by a laminin-rich gel. Evidence for a functionally significant subendothelial matrix in normal rat liver. J. Clin. Invest. 79:801-812.

35. Kavanaugh, W.M., and L.T. Williams. 1994. An alternative to SH2 domains for binding tyrosine-phosphorylated proteins. Science (Wash. DC). 266 : 1862-1865.

36. Pawson, T. 1995. Protein modules and signaling networks. Nature (Lond.). 373:573-580

37. Araki, E., M.A. Lipes, M.E. Patti, J.C. Bruning, B. Haag III., R.S Johnson, and C.R. Kahn. 1994. Alternative pathway of insulin signalling in mice with targeted disruption of the IRS-1 gene. Nature (Lond.). 372:186-190.

38. Yonezawa, K., A. Ando, Y. Kaburagi, R. Yamamoto-Honda, T. Kitamura, K. Hara, M. Nakafuku, Y. Okabayashi, T. Kadowaki, Y. Kaziro, et al 1994. Signal transduction pathways from insulin receptors to Ras. Analysis by mutant insulin receptors. J. Biol. Chem. 269:4634-4640.

39. Myers, M.G., T.C. Grammer, J. Brooks, E.M. Glasheen, L.M. Wang, X J. Sun, J. Blenis, J.H. Pierce, and M.F. White. 1995. The pleckstrin homology domain in insulin receptor substrate-1 sensitizes insulin signaling. J. Biol. Chem. 270:11715-11718.

40. Touhara, K., J. Inglese, J.A. Pitcher, G. Shaw, and R.J. Lefkowitz. 1994. Bindings of $\mathrm{G}$ protein beta gamma-subunits to pleckstrin homology domains. $J$. Biol. Chem. 269:10217-10220.

41. Harlan, J.E., P.J. Hajduk, H.S. Yoon, and S.W. Fesik. 1994. Pleckstrin homology domains bind to phosphatidylinositol-4, 5-bisphosphate. Nature (Lond.). 371:168-170.

42. Vuori, K., and E. Ruoslhti. 1994. Association of insulin receptor substrate-1 with integrins. Science (Wash. DC). 266:1576-1578.

43. DiPersio, C.M., D.A. Jackson, and K. Zaret. 1991. The extracellular matrix coordinately modulates liver transcription factors and hepatocyte morphology. Mol. Cell. Biol. 11:4405-4414.

44. Aaronson, S.A. 1991. Growth factors and cancer. Science (Wash. DC). 254:1146-1153.

45. Sugimoto, S., T.J. Wandless, S.E. Shoelson, B.G. Neel, and C.T. Walsh 1994. Activation of the SH2-containing protein tyrosine phosphatase. SH PTP2, by phosphotyrosine-containing peptides derived from insulin receptor substrate-1.J. Biol. Chem. 269:13614-13622.

46. Sabe, H., A. Hata, M. Okada, H. Nakagawa, and H. Hanafusa. 1994. Analysis of the binding of the Src homology 2 domain of Csk to tyrosine-phosphorylated proteins in the suppression and mitotic activation of c-Src. Proc. Natl. Acad. Sci. USA. 91:3984-3988.

47. Rotin, D., A.M. Honegger, B.L. Margolis, A. Ullrich, and J. Schlessinger. 1992. Presence of SH2 domains of phospholipase C gamma 1 enhances substrate phosphorylation by increasing the affinity toward the epidermal growth factor receptor. J. Biol. Chem. 267:9678-9683.

48. Cowley, S., H. Paterson, P. Kemp, and C.J. Marshall. 1994. Activation of MAP kinase kinase is necessary and sufficient for PC12 differentiation and for transformation of NIH 3T3 cells. Cell. 77:841-852.

49. Mansour, S.J., W.T. Matten, A.S. Hermann, J.M. Candia, S. Rong, K. Fukasawa, G.F. Vande Woude, and N.G. Ahn. 1994. Transformation of mammalian cells by constitutively activated MAP kinase kinase. Science (Wash. DC). 265:966-970. 